\title{
AN ANALYSIS OF FINANCIAL INDICATORS: A COMPARISON BETWEEN DIGITAL BANK AND CONSOLIDATED BANKS
}

\author{
Rayssa Kawanne dos Santos and Maria Helena da Silva Gonzaga \\ Universidade Estadual de Alagoas, Brazil
}

\begin{abstract}
Currently there is a possible fourth industrial revolution, with artificial intelligence, industry 4.0 and it could not happen differently in the financial market. Fintechs or new startups work to innovate and optimize financial market services, promising to revolutionize the branch in Brazil. However, to what extent can it be trusted that their models have profitability and efficiency as consolidated institutions? From this, this work aims to analyze, through financial indicators, balance sheets and income statements of two major banks operating in Brazil, Itaú and Bradesco, and compare them with Inter, the only fintech listed on the São Paulo stock exchange. Thus, this work has as main objective to verify whether there is a discrepancy between the economic and financial indicators of these institutions. The results showed that the biggest differences are in the leverage indices, with Inter averaging 9.10 and Itaú and Bradesco, respectively, 10.08 and 10.85; fixed capital, with Inter Bank having an average percentage equivalent to $1.45 \%$ and the remaining $7.56 \%$ and $5.58 \%$; in addition to the return on equity, in this indicator Inter Bank has a statistically average percentage of $9.76 \%$ and Itaú $16.36 \%$ and Bradesco $15.88 \%$, this can be justified by the structural differences of financial institutions in relation to the recognition and measurement of leasing operations, revenue related to credit operations, and other variables that may contribute to the increase or decrease in indicators. In the other indicators used, different statistical results were found, but not statistically relevant.
\end{abstract}

\section{KEYWORDS}

Fintechs, Indicators, Industry 4.0

\section{INTRODUCTION}

Over the years, constant technological innovations emerged and the industry underwent several changes that altered the development of society. It is important to remember that revolutions occur when new technologies and new ways of perceiving the world cause a profound change in social structures and economic systems. In this context, the fourth industrial revolution emerged as a pillar of connectivity and development.

Industry 4.0 also called the digital revolution is characterized by a mobile internet made possible by the smartphone, in addition to the advent of artificial intelligence. In this way, financial institutions have been developing technologically to meet market demands. New technology-based business models and digital innovations related to financial services are called "Finance Technologies" or simply Fintechs.

Given this perspective, it was questioned to what extent it can be trusted that the new business models of digital banks have profitability and efficiency like the consolidated institutions. The main objective of this study is based on analyzing, through financial indicators, the profitability and efficiency of the two main private banks in Brazil - Itaú and Bradesco - and to compare with Inter Bank, the only fintech listed on the stock exchange of São Paulo. It is also intended, through the specific objectives, to conceptualize the term Fintech; identify financial indicators that show the profitability and efficiency of financial institutions; explain the challenges for the growth of fintechs, and finally, calculate the chosen financial ratios, so that it is possible to present the results obtained.

Studying the efficiency and profitability of Brazilian fintechs assumes increasing importance, since the structure of the banking business has been the target of change around the world (Mendonça and Souza, 2017). In this way, the article will offer subsidies for understanding the efficiency and profitability of financial 
institutions and assist in the knowledge of the digital financial industry, which may arouse the interest of managers, investors, analysts, the academic community and regulatory bodies in the banking sector.

The structure of the present work consists of five sections, this introduction being the first. The theoretical framework is summarized in the second section, and in the third, the methodological procedures adopted are described. Section four presents the results obtained by the research and the final considerations are contained in the last and fifth section.

\section{RELATED WORK / LITERATURE REVIEW}

\subsection{Fintech}

In the middle of 1866 towards the end of the seventeenth century, there was a great financial revolution in Europe, which allowed the advent of insurance, banks and a stock market that was very essential for the industrial development of the time, from that moment on technology begins to enter the financial market.

According to the analyzes of Arner, Barberis and Buckley (2015), during the years from 1967 to 1987 there was a migration from analogue to digital financial services. According to them, there was a need for domestic connectivity in the payments area, causing branches to be created or updated, moving from the old telegraph system to a new electronic system. This way, Fintech term can be considered as a "technology-enable innovation in financial services, regardless of the nature or size of the provider of the services" (The European Commission, 2017).

The authors Haddad and Hornuf (2016) tried to answer the following question: why do some countries have more startups with the intention of changing the financial industry through innovation and digitalization than others? They evaluated a total of 64 countries, using more than 200.000 data from companies, 2.000 data from speculative partners and millions of information points on the internet to try to understand how economic and technological conditions could be influencing the formation of Fintechs. To carry out the study, they raised six hypotheses, of which five were confirmed.

The five that were confirmed were: "Fintechs appear more frequently in countries with a more developed capital market", this would be due to the ease of financing and the fact that a more heated stock market would bring opportunity for Fintechs; "The emergence of Fintechs is more frequent in countries with cutting-edge technology", as there would be more opportunities to build technology-based business models on a more robust and technological infrastructure; "Fintech is more common in countries with more cell phone line subscriptions", this would be due to the fact that in countries with difficult access to financial institutions, cell phones would be the most practical platform for startups in Fintech to supply the need for these people; "The formation of startups at Fintechs occurs more in countries with a weakened financial sector", the explanation would be the lack of credibility of financial institutions, for this reason the consumer would be more open to accepting new companies entering the sector. "The formation of Fintechs is favored when there is a large labor market in the country", the authors defend, through empirical evidence, that a more populous country has a higher percentage of entrepreneurs in its workforce, so the greater the strength more "offer" of entrepreneurs and more startups and, therefore, more Fintechs.

\subsection{Inter}

According to its institutional website, Inter had its foundation in 1994, being one of the first digital banks in Brazil, the initial purpose was to promote real estate credit operations, however the company consolidated itself in the payroll and middlie market, medium-sized companies postage. In 2014, Inter launched the digital account, with a totally free checking account that can be accessed by computers and cell phone, allowing deposits, transfers, payment of slips, withdrawals at a 24-hour bank, among other services. As of April 2016, Central Bank of Brazil Resolution No. 4,480 began to take effect, facilitating the opening of new digital accounts. In 2018, Banco Inter announces its initial public offering at B3, with shares priced at R \$ 18.50. In 2019 it updated its application for smartphones with a new tool that allows customers to have cashback when shopping in several stores. 


\subsection{Financial Ratios}

The profitability of banks has always been the target of many discussions in the financial market, which is an important criterion in the analysis of the results of financial institutions. Through the profitability analysis it is possible to identify the success of the competitive strategies of the institutions that operate in similar environments (Dietrich, A. and Wanzenried, G., 2011). The formulas for calculating the financial indicators used in the analysis and the respective definitions are presented in table 1, according to Marion (2002).

Table 1. Distribution of indicators and respective calculation formulas

\begin{tabular}{|c|c|c|}
\hline \multicolumn{3}{|c|}{ SOLVENCY AND LIQUIDITY INDICATORS } \\
\hline NAME/INITIALS & FORMULA & DEFINITION \\
\hline $\begin{array}{l}\text { Loan to Deposit } \\
\text { Ratio (LDR) }\end{array}$ & $\mathrm{LDR}=\frac{\text { Credit operations }}{\text { Deposit }}$ & $\begin{array}{l}\text { Is used to assess a bank's liquidity by comparing } \\
\text { a bank's total loans to its total deposits for the } \\
\text { same period. If the index is too high, it means that } \\
\text { the bank may not have enough liquidity to cover } \\
\text { any unforeseen fund requirements. }\end{array}$ \\
\hline $\begin{array}{l}\text { Loan Participation } \\
\text { Ratio (LPR) }\end{array}$ & $\mathrm{LPR}=\frac{\text { Credit operations }}{\text { Total assets }}$ & $\begin{array}{l}\text { Measures the participation of credit operations in } \\
\text { relation to the institution's total assets, such index } \\
\text { being inversely proportional to the liquidity } \\
\text { index, but directly proportional to the increase in } \\
\text { operating results. }\end{array}$ \\
\hline \multicolumn{3}{|c|}{ CAPITAL AND RISK INDICATORS } \\
\hline $\begin{array}{l}\text { Leverage Ratio } \\
\text { (LR) }\end{array}$ & $\mathrm{LR}=\frac{\text { Return on Equity }}{\text { Return on Assets }}$ & $\begin{array}{l}\text { Represents the Degree of Financial Leverage, the } \\
\text { higher the index, the greater the company's ability } \\
\text { to generate returns for its owners. }\end{array}$ \\
\hline $\begin{array}{l}\text { Fixed Assets to Net } \\
\text { Worths Ratio } \\
\text { (FANWR) } \\
\end{array}$ & FANWR $=\frac{\text { Fixed Assets }}{\text { Net Worths }}$ & $\begin{array}{l}\text { Identifies all investments in physical assets } \\
\text { intended for the normal operation of the } \\
\text { company's operating activities. }\end{array}$ \\
\hline \multicolumn{3}{|c|}{ PROFITABILITY INDICATORS } \\
\hline $\begin{array}{l}\text { Gross Margin } \\
\text { Ratio (GMR) }\end{array}$ & $\mathrm{GMR}=\frac{\text { Gross income financial intermediation }}{\text { Financial intermediation revenue }}$ & $\begin{array}{l}\text { Measures, in percentage, how much is left of the } \\
\text { sale of products less the costs of products sold. }\end{array}$ \\
\hline $\begin{array}{l}\text { Efficiency Ratio } \\
\text { (ER) }\end{array}$ & $\mathrm{ER}=\frac{\text { Operation Expenses }}{\text { Financial intermediation revenue }}$ & $\begin{array}{l}\text { Represents the operational efficiency of the } \\
\text { financial institution. }\end{array}$ \\
\hline $\begin{array}{l}\text { Net Profit Margin } \\
\text { Ratio (NPMR) }\end{array}$ & $\mathrm{NPMR}=\frac{\text { Net income }}{\text { Financial intermediation revenue }}$ & $\begin{array}{l}\text { Represents the efficiency of expenses in relation } \\
\text { to sales, because the lower the expenses, the } \\
\text { greater the profit margin. }\end{array}$ \\
\hline $\begin{array}{l}\text { Asset Turnover } \\
\text { Ratio (ATR) }\end{array}$ & $\mathrm{ATR}=\frac{\text { Financial intermediation revenue }}{\text { Total assets }}$ & $\begin{array}{l}\text { Demonstrates how much of the bank's total } \\
\text { investments (total assets) have been converted } \\
\text { into financial intermediation revenue. }\end{array}$ \\
\hline $\begin{array}{l}\text { Return on Assets } \\
\text { Ratio (RAR) }\end{array}$ & $\mathrm{RAR}=\frac{\text { Net income }}{\text { Total assets }}$ & $\begin{array}{l}\text { Demonstrates the result of business opportunities } \\
\text { triggered by the company, measuring profit in } \\
\text { relation to the company's assets, that is, profit for } \\
\text { each } \$ 1 \text { in assets. }\end{array}$ \\
\hline $\begin{array}{l}\text { Return on Equity } \\
\text { Ratio (RER) }\end{array}$ & $\mathrm{RER}=\frac{\text { Net income }}{\text { Shareholder's equity }}$ & $\begin{array}{l}\text { Measures how efficiently a company is using its } \\
\text { equity to generate profit. }\end{array}$ \\
\hline
\end{tabular}

\section{METHODOLOGY}

This study is characterized as a quantitative and descriptive study as it seeks to analyze financial data. In a quantitative research, according to Prodanov and Freitas (2013), all information is quantifiable, described by means of numbers, to be classified and analyzed. In the descriptive research, according to Prodanov and Freitas 
(2013), "the facts are observed, recorded, analyzed, classified and interpreted, without the researcher interfering with them".

As for the procedure used, the most important element is data collection, being classified into two groups: those whose information is gathered from people, giving rise to experimental research, ex-post facto research, case study among others. When data are not collected from people, but from documentary sources, they give rise to bibliographic and documentary research (Prodanov, C. C. and Freitas, E. C., 2013).

To define the institutions to be analyzed, the Central Bank of Brazil (BCB) records were consulted in order to identify the main banking institutions in Brazil. Secondary data obtained through the BCB annual report entitled "The 100 largest banks" available on the BCB website (2017) was used. Thus, the sample is composed of 03 private companies with shares traded on the Stock Exchange (B3): Itaú, Bradesco and Inter, the latter being the only Brazilian fintech to disclose its statements at B3 and the first two Brazilian private banks with the largest rise.

In order to choose the financial indicators used in the analysis, it was necessary to look in the existing bibliography for those that measure the financial situation of the banks, since not all conventional indicators made available are applicable due to the operational activity of banking financial institutions. After selecting the indicators in the existing literature, the indices were calculated from the proposed formulas for each indicator and performed using Microsoft Excel software spreadsheets.

This work being made from documents published by institutions in B3 without the need to collect data from members of it, it is characterized as documentary research. The sample was chosen for access and convenience, since the sample used was due to the size of the banks and the accessibility of financial information. Data were collected for the years 2016, 2017 and 2018, and the Inter indexes in that last year were distorted because of the IPO on the São Paulo stock exchange.

\section{DATA ANALYSIS AND RESULT}

The analysis of the economic and financial indicators was based on the indicator model proposed by Assaf Neto (2015) in order to make a comparison between the institutions and to know the behavior of their results. Although calculated, the indexes for the year 2018 of the three institutions were used only as a support base because of the discrepancy found in the Inter indexes, with only the 2016 and 2017 indexes of the three banks being analyzed for an effective comparison.

\subsection{Solvency and Liquidity}

Inter is the institution that has the second highest Loan to Deposit ratio in both 2016 and 2017. This ratio increases its revenue potential, however it decreases the bank's ability to serve a high volume of withdrawals in the accounts.

Table 2. Comparison of Bank Solvency and Liquidity indexes

\begin{tabular}{l|lll|lll}
\hline & \multicolumn{3}{|c|}{ Loan to Deposit } & \multicolumn{3}{c}{ Loan Participation } \\
\hline Financial institution & 2016 & 2017 & 2018 & 2016 & 2017 & 2018 \\
\hline Inter & $81,16 \%$ & $85,16 \%$ & $76,23 \%$ & $70,37 \%$ & $72,73 \%$ & $61,59 \%$ \\
Bradesco & $68,44 \%$ & $57,00 \%$ & $78,62 \%$ & $42,38 \%$ & $34,14 \%$ & $51,33 \%$ \\
Itaú & $91,87 \%$ & $88,40 \%$ & $88,84 \%$ & $66,77 \%$ & $63,06 \%$ & $64,06 \%$ \\
\hline
\end{tabular}

As shown in table 2, its credit operations account for an average of $70 \%$ of all its assets, this increases the operating result, but on the other hand it demonstrates a possible lack of liquidity, since credit operations are non-negotiable until their Due date. The difference between the participation of loans from Itaú and Bradesco to Inter is approximately 10 and 39 percentage points, respectively. 


\subsection{Capital and Risk}

As shown in Table 3, Inter has the lowest risk levels of all institutions, its leverage is the lowest, and due to its characteristic of being $100 \%$ digital, its capital immobilization has the lowest index, leaving its own resources free for loans.

Table 3. Comparison of Bank Capital and Risk indexes

\begin{tabular}{l|lll|lll}
\hline & \multicolumn{3}{|c|}{ Leverage } & \multicolumn{3}{c}{ Fixed assets to net worths } \\
\hline Financial institution & 2016 & 2017 & 2018 & 2016 & 2017 & 2018 \\
\hline Inter & 9,0276 & 9,1774 & 6,0319 & $1,48 \%$ & $1,42 \%$ & $1,48 \%$ \\
Bradesco & 11,3011 & 10,4029 & 10,4715 & $7,96 \%$ & $7,16 \%$ & $7,08 \%$ \\
Itaú & 10,2075 & 9,9493 & 10,3199 & $6,07 \%$ & $5,10 \%$ & $4,85 \%$ \\
\hline
\end{tabular}

\subsection{Profitability}

Table 4. Comparison of Bank Profitability and Profitability indexes

\begin{tabular}{l|lll|lll}
\hline & \multicolumn{3}{|c|}{ Gross margin } & \multicolumn{3}{c}{ Efficiency } \\
\hline Financial institution & 2016 & 2017 & 2018 & 2016 & 2017 & 2018 \\
\hline Inter & $44,46 \%$ & $44,41 \%$ & $64,63 \%$ & $42,71 \%$ & $49,56 \%$ & $67,21 \%$ \\
Bradesco & $44,12 \%$ & $45,14 \%$ & $50,91 \%$ & $40,61 \%$ & $50,20 \%$ & $63,11 \%$ \\
Itaú & $45,64 \%$ & $47,63 \%$ & $46,23 \%$ & $46,74 \%$ & $53,69 \%$ & $55,68 \%$ \\
\hline
\end{tabular}

As shown in Table 3 despite having a lean structure, Inter has the worst Efficiency Ratio in 2017 and the second best in 2016. However, due to its digital strategy, its expansion does not require a large increase in operating expenses, thus, an increase your customer base should improve your efficiency.

Due to its characteristic of not charging fees and its revenue from services rendered, it has little expressiveness in relation to total revenues, Inter has the lowest net margin among the analyzed banks, as shown in the table below.

Table 5. Comparison of Bank Profitability and Profitability Indexes

\begin{tabular}{l|lll|lll}
\hline & \multicolumn{3}{|c|}{ Net profit margin } & \multicolumn{3}{c}{ Asset turnover } \\
\hline Financial institution & 2016 & 2017 & 2018 & 2016 & 2017 & 2018 \\
\hline Inter & $4,47 \%$ & $9,59 \%$ & $9,08 \%$ & $18,10 \%$ & $13,87 \%$ & $10,92 \%$ \\
Bradesco & $11,04 \%$ & $12,57 \%$ & $14,88 \%$ & $13,67 \%$ & $11,25 \%$ & $8,62 \%$ \\
Itaú & $12,58 \%$ & $15,53 \%$ & $19,52 \%$ & $12,95 \%$ & $10,41 \%$ & $8,46 \%$ \\
\hline
\end{tabular}

The lower need for assets for Inter's operations means that it has the highest profitability of assets, with $18,10 \%$ in 2016 and 13,87\% in 2017. Despite its lower need for assets, we can see in table 6 that the bank has the lowest Return on Assets Ratio.

Table 6. Comparison of Bank Profitability and Profitability Indexes

\begin{tabular}{l|lll|lll}
\hline & \multicolumn{3}{|c|}{ Return on assets } & \multicolumn{3}{c}{ Return on equity } \\
\hline Financial institution & 2016 & 2017 & 2018 & 2016 & 2017 & 2018 \\
\hline Inter & $0,81 \%$ & $1,33 \%$ & $0,99 \%$ & $7,31 \%$ & $12,21 \%$ & $5,98 \%$ \\
Bradesco & $1,51 \%$ & $1,41 \%$ & $1,28 \%$ & $17,06 \%$ & $14,71 \%$ & $13,43 \%$ \\
Itaú & $1,63 \%$ & $1,62 \%$ & $1,65 \%$ & $16,63 \%$ & $16,09 \%$ & $17,04 \%$ \\
\hline
\end{tabular}

Although Inter has an increase in the Return on Equity index when compared to the years under analysis, it ranks last in the list of banks analyzed. If the institution increased its degree of leverage to levels of the average of other banks, 12 times, its Return on Equity would be the highest among banks.

In light of this, it is evident that Inter's Efficiency and Net Margin is likely to increase in the coming years due to the increase in customers and the bank's broad portfolio of services. On the other hand, due to its sudden increase in shareholders 'equity, due to the IPO at B3, the return on shareholders' equity should return to average levels more slowly, but it is precisely this capitalization that enables the bank to grow more. 


\section{CONCLUSION}

The fourth industrial revolution emerged as a pillar of connectivity and development, with which the financial market has been developing technologically, especially in the digital sector. Thus, the objective of our work was to compare the efficiency and profitability of digital banks, with Inter as an example of digital bank, with other traditional financial institutions, to understand whether the new practices and strategy coming from digital structures are in fact more profitable and efficient than traditional structures.

Currently, Inter Bankis the only 100\% digital institution to offer a complete range of banking products and services. Although traditional banks are adapting to digital resources, the large number of physical branches diminishes their efficiency. On the other hand, Inter's business model makes it unnecessary to hire too many employees, which increases the bank's efficiency, but its operating expenses still add up to around $50 \%$ of financial intermediation revenues. If Inter is able to expand its customer base and credit portfolio without increasing operating and administrative expenses, this efficiency will be even greater. If Inter increases its leverage to the average of other banks, it would have the second highest return. The main differences found when comparing the indices of the three banks are in relation to the structures of organizations, revenues related to credit operations and the recognition and measurement of leasing operations. These differences can be considered the main limitation of the research.

It is worth mentioning that the evidence found and discussed in this research must be considered taking into account the limitations of the methodology and the sample selection criteria. For future studies, it is suggested to analyze a larger sample of Brazilian financial institutions, including state-owned banks. In addition, it would be interesting to investigate the strategies that fintechs can adopt to increase their efficiency levels and also carry out a comparison between digital banks from different countries, thus analyzing how the political and social environment impacts the financial results of institutions.

The evidence presented in this article is expected to contribute as a new vision for the financial technology industry and to increase knowledge about the Fintech market and the importance of studying efficiency and profitability for the financial health of institutions.

\section{REFERENCES}

Arner, D. W. Et al, 2015. The evolution of fintech: a new post-crisis paradigm?. University of Hong Kong Faculty of Law Research Paper, vol. 2015/047, pp. 1689-1699.

Assaf Neto, A. A., 2015. Estrutura e Análise de Balanços(11th ed.). Atlas, São Paulo, Brazil.

B3 (Brazil), 2019. Empresas Listadas. [Online] Available at: http://www.b3.com.br/pt_br/produtos-eservicos/negociacao/renda-variavel/empresas-listadas.htm [Accessed 04 November 2019].

Dietrich, A. and Wanzenried, G., 2011. Determinants of bank profitability before and during the crisis: Evidence

European Commission, 2017. Public consultation on FinTech: a more competitive and innovative European financial sector. [Online] Available at: https://ec.europa.eu/info/consultations/finance-2017-fintech_en [Accessed 27 November 2019].

from Switzerland. Journal of International Financial Markets, Institutions \& Money, v. 21, pp. 307-327.

Gitman, J., 2003. Princípios da Administração Financeira (10th ed.). Pearson, São Paulo, Brazil.

Haddad, C. and Hornuf, L., 2016. The Emergence of the Global Fintech Market: Economic and Technological Determinants. SSRN Electronic Journal. doi: 10.2139/ssrn.2830124.

Mantovani, M. H. C. And Dos Santos, J. O., 2015. Análise da relação entre alavancagem e rentabilidade. REGE, v. 22, n. 4, pp. 509-524, São Paulo, Brazil.

Marion, J. C., 2002. Análise das Demonstrações Contábeis (2nd ed.). Atlas, São Paulo, Brazil.

Matarazzo, D. C., 2010. Análise Financeira de Balanços (7th ed.). Atlas, São Paulo, Brazil.

Mendonça, D. J. and Souza, J. A., 2017. Análise da relação entre eficiência e rentabilidade das instituições financeiras bancárias brasileiras: um estudo utilizando a análise envoltória de dados (DEA). XXXVII Encontro Nacional de Engenharia de Produção. Santa Catarina, Brazil.

Prodanov, C. C. and De Freitas, E. C., 2013. Metodologia do Trabalho Científico. FEEVALE, Rio Grande do Sul, Brazil. Ross, S. A. et al., 2015. Administração Financeira (10th ed.). AMGH Editora Ltda, Porto Alegre, Brazil.

Marion, J. C., 2002. Análise das Demonstrações Contábeis (2nd ed.). Atlas, São Paulo, Brazil. 